\title{
In vitro efficacy of different fungicides against Alternaria macrospora causing leaf blight of cotton
}

\author{
Somashekhar Nagappa Meti and V.R. Kulkarni*
}

Department of Plant Pathology, College of Agriculture, University of Agricultural Sciences, Dharwad (Karnataka) India

\section{ARITCLE INFO}

Received : 17.01 .2020

Revised : 05.02 .2020

Accepted : 20.02.2020

\section{KEY WORDS :}

In vitro evaluation, Systemic, Non systemic, Combi product fungicides, Alternaria macrospora

*Corresponding author: Email : kulkarnivr@uasd.in

\begin{abstract}
A total of sixteen fungicides which included six systemic, five non systemic and five combi products which differed significantly with respect to fungicides concentrations and their interactions were evaluated for their efficacy against Alternaria macrospora by poisoned food technique. Among the six systemic fungicides evaluated against $A$. macrospora, hexaconazole and propiconazole recorded the cent per cent inhibition of mycelial growth at all the concentrations $(0.05 \%, 0.1 \%$ and $0.15 \%)$ and least inhibition of mycelial growth was recorded by carbendazim $(26.01 \%)$. Out of five non systemic fungicides evaluated, mancozeb recorded the maximum inhibition of 95.29 per cent followed by captan 92.68 per cent and copper oxy chloride recorded the minimum inhibition of 68.7 per cent. Among five combi fungicides evaluated in vitro (tebuconazole $50 \%+$ trifloxystrobin $25 \%$ ) recorded the complete inhibition (100\%) at all concentrations $(0.1 \%, 0.2 \%$ and $0.3 \%)$ and least inhibition of mycelial growth 86.01 per cent was recorded by (captan $70 \%+$ hexaconazole $5 \%$ ).
\end{abstract}

How to view point the article : Meti, Somashekhar Nagappa and Kulkarni, V.R. (2020). In vitro efficacy of different fungicides against Alternaria macrospora causing leaf blight of cotton. Internat. J. Plant Protec., 13(1) : 14-17, DOI : 10.15740/HAS/IJPP/13.1/14-17, Copyright@ 2020: Hind Agri-Horticultural Society. 